Preston, N. W. \& Martland, H. B. (1952). J. gen. Microbiol. 7, 117-128

\title{
The Influence of Temperature on the Motility of Pasteurella pseudotuberculosis
}

\author{
By N. W. PRESTON AND H. B. MAITLAND \\ Department of Bacteriology, University of Manchester
}

\begin{abstract}
SUMMARY: Grown at $22^{\circ}$ Pasteurella pseudotuberculosis was motile and had flagella and $H$ antigen; grown at $37^{\circ}$ it was non-motile and had neither flagella nor $H$ antigen. The change occurred over a narrow range of temperature about $30^{\circ}$. Cells grown at $37^{\circ}$ when transferred to $22^{\circ}$ developed flagella without cell division; cells grown at $22^{\circ}$ when transferred to $37^{\circ}$ became non-motile, due to an unexplained adverse effect indicated by a high death-rate. It appeared that different metabolic processes were used at the two temperatures; it was not necessary to postulate the selection of a naturally occurring mutant and no evidence was obtained for the existence of an extracellular enzyme which would destroy flagella at $37^{\circ}$.

In addition to the 'short-term' effect there was a 'long-term' effect of temperature shown by a difference in degree of motility and rate of growth (at $22^{\circ}$ ) of cultures grown for several months at 22 or $37^{\circ}$. This may have been an extension of the 'short-term ' effect, a period of training being required for the optimal functioning of the metabolic processes concerned. The long-term effect could be reversed by prolonged cultivation of the $22^{\circ}$ substrain at $37^{\circ}$ and vice versa.

Preliminary experiments indicated that virulence was affected by the temperature of cultivation.
\end{abstract}

A survey of the literature shows fairly general agreement that Pasteurella pseudotuberculosis is non-motile at $37^{\circ}$ but motile at about $\mathbf{2 2}^{\circ}$ (Arkwright, 1927; Boquet, 1937; Bhatnagar, 1940). However, Boquet noted that two strains became permanently non-motile, even at $20^{\circ}$, after culture at $37^{\circ}$ for several years; one of Arkwright's strains was slightly motile at $37^{\circ}$; Weitzenberg (1935) observed a few short granular flagella on organisms grown at $37^{\circ}$. Schütze (1932) showed that all four types of Past. pseudotuberculosis, based on somatic antigens, produced a common flagellar antigen at room temperature. Boquet claimed that a flagellar antigen was produced at $37^{\circ}$, but gave no convincing proof.

The object of the present work was to explain the mechanism by which the temperature of incubation affected the production of flagella.

\section{MATERIALS AND METHODS}

A single strain (134) of Past. pseudotuberculosis which had been isolated from a guinea-pig and dried was used for the main experimental work. By subculture twice a week for several months in Craigie tubes at $22^{\circ}$ and on agar slopes at $37^{\circ}$, two new substrains were produced, referred to as $134 / 22$ and 134/37. They were maintained similarly, the medium in each case being prepared from tryptic digest broth. The parent strain and the substrains were alike in not fermenting lactose or sucrose; they produced acid (without gas) from glucose and mannitol in $24 \mathrm{hr}$., and from salicin in 5-7 days. Indole was not produced. 
The strain was pathogenic for mice and guinea-pigs by intraperitoneal injection of broth cultures but its virulence was low; subcutaneous injection produced a non-progressive local lesion which became sterile after a few weeks. It was not pathogenic for white rats.

Other strains were obtained from the National Collection of Type Cultures. To detect motility broth cultures were examined in a 'hanging-drop'.

The staining technique for flagella was developed from a modification of Gray's method (Conn \& Wolfe, 1938) and yielded clean preparations with deeply stained flagella:-

Stand new slides in concentrated nitric acid for at least $24 \mathrm{hr}$.; wash in distilled water; rinse in ethanol; pass them through the Bunsen flame until it turns slightly orange; cool gradually on an asbestos mat, to minimize breakage.

With a cool loop, transfer a little growth from an overnight agar slope culture to a few ml. of sterile distilled water; allow to stand for 5-10 min.; put a loopful on a slide, and spread with the edge of another slide; allow to dry without heating. By using the deposit from a centrifuged overnight broth culture (as suggested by Leifson, 1930), allowing this to stand in water for only 2-3 min. before smearing, a better result may be obtained. The agar slope, or broth, should be inoculated with motile organisms from a Craigie tube.

Apply cold mordant for 10-15 min.; wash well in running water; blot gently, and dry in the air without heating; apply cold stain for 7-10 min; wash, and blot dry.

Mordant. Mix $5 \mathrm{ml}$. saturated aqueous potassium alum, $2 \mathrm{ml}$. saturated aqueous mercuric chloride, $2 \mathrm{ml} .20 \%(\mathrm{w} / \mathrm{v})$ aqueous tannic acid, and $0.4 \mathrm{ml}$. saturated ethanolic basic fuchsin; allow to stand for $\mathbf{2} \mathrm{hr}$.; filter twice through Whatman No. 1 filter-paper and use immediately.

Stain. Heat $15 \mathrm{~g}$. phenol with $3 \mathrm{~g}$. basic fuchsin on a water-bath; when completely dissolved, add $30 \mathrm{ml}$. ethanol; mix thoroughly; add $170 \mathrm{ml}$. distilled water; leave for at least $24 \mathrm{hr}$.; filter 3 times through Whatman No. 1 filterpaper just before use.

\section{RESULTS}

Motility and flagellation. Broth cultures grown for $48 \mathrm{hr}$. at $22^{\circ}$ showed a general turbidity and fine deposit, and contained short actively motile rods. Similar cultures grown at $37^{\circ}$ had a granular deposit, a surface pellicle, and a few scattered floccules, but no general turbidity; they consisted of longer non-motile rods. Stained preparations of agar slope cultures grown at $\mathbf{2 2}^{\circ}$ revealed organisms with one to six peritrichate flagella, more commonly only one or two (Pl. 1, fig. 1). It was later observed that stained deposits of broth cultures showed more numerous flagella (Pl. 1, fig. 2) and this method alone was subsequently used for their demonstration. Organisms grown at $37^{\circ}$, however, showed no flagella (Pl. 1, fig. 3). There is apparently a gradual change (over a small range of temperature about $30^{\circ}$ ) from active motility to complete absence of motility (Table 1 ).

Both substrains $134 / 37$ and $134 / 22$ grew round Craigie tubes at $22^{\circ}$ in 1 to 4 days, depending upon the consistency of the medium. At $37^{\circ}$ the 
Table 1. Effect of temperature on motility, morphology and growth in broth

\begin{tabular}{|c|c|c|}
\hline \multirow[b]{2}{*}{ Temperature } & \multicolumn{2}{|c|}{ Appearance of culture } \\
\hline & Macroscopic & Microscopic \\
\hline $25^{\circ}$ & Turbid & $\begin{array}{l}80 \% \text { actively motile: mostly short } \\
\text { bacilli, single or in pairs }\end{array}$ \\
\hline $27^{\circ}$ & Turbid & $\begin{array}{l}80 \% \text { actively motile : mostly short } \\
\text { bacilli, single or in pairs }\end{array}$ \\
\hline $29^{\circ}$ & Diffuse floccules & $\begin{array}{l}50 \% \text { slowly motile: many long } \\
\text { bacilli and chains }\end{array}$ \\
\hline $31 \cdot 5^{\circ}$ & $\begin{array}{l}\text { Deposit and few } \\
\text { floccules }\end{array}$ & $\begin{array}{l}\text { One motile cell seen (very sluggish) } \\
\text { mostly long bacilli and long chains }\end{array}$ \\
\hline $34^{\circ}$ & $\begin{array}{l}\text { Deposit and few } \\
\text { floccules }\end{array}$ & $\begin{array}{l}\text { Non-motile: mostly long bacilli and } \\
\text { long chains }\end{array}$ \\
\hline
\end{tabular}

growth of strain $134 / 37$ was confined to the line of inoculation, whilst strain 134/22 produced a more diffuse growth in the upper part of the medium within the central glass tube, but never reached the surface outside. This inability to grow round a Craigie tube at $37^{\circ}$, even after 2 weeks' incubation in a tube which had been sealed to prevent evaporation, provides further evidence in favour of a complete absence of motility. The diffuse growth of strain 134/22 was obtained even when the Craigie tube was warmed to $37^{\circ}$ before inoculation, the inference being that bacteria in the inoculum retained their motility for a time at $37^{\circ}$ and spread some way into the medium where they grew. Such temporary maintenance of motility at $37^{\circ}$ was again apparent in later experiments.

$H$ antigen. Rabbits were immunized with flagellated and non-flagellated organisms grown at 22 and $37^{\circ}$ respectively. The growth from $48 \mathrm{hr}$. cultures on blood agar plates was suspended in normal saline containing $0.1 \%(\mathrm{v} / \mathrm{v})$ formalin. After standing at $4^{\circ}$ until sterile, the suspensions were diluted to about $5 \times 10^{8}$ organisms $/ \mathrm{ml}$., and stored at $4^{\circ}$. Each rabbit received $0.5 \mathrm{ml}$. suspension intravenously on three successive days in the first week, and three doses of $1.0 \mathrm{ml}$. in each of the second and third weeks. Samples of blood were taken at weekly intervals before, during, and after the course of injections, and the sera, preserved with $0.5 \%(\mathrm{w} / \mathrm{v})$ phenol, were stored at $4^{\circ}$.

Suspensions for agglutination were made from cultures grown at $\mathbf{2 2}^{\circ}$. The ' $\mathrm{H}$ ' suspensions were made by diluting twofold the one used for immunization. The ' $O$ ' suspensions were made by boiling saline suspensions for $2 \mathrm{hr}$. and diluting them to the same density. The instability of suspensions of Past. pseudotuberculosis from cultures grown at $37^{\circ}$ was recorded by Arkwright (1927). We were able to produce a relatively stable suspension from such cultures by shaking before boiling, but the tendency to auto-agglutination was not completely removed and the agglutination end-points were consequently less distinct than with organisms grown at $22^{\circ}$. The titres of $\mathbf{H}$ and $\mathrm{O}$ agglutinins were obtained by using Dreyer tubes, held overnight at $56^{\circ}$ in a water-bath. The results are shown in Table 2 . Sera made against organisms grown at $22^{\circ}$ contained both $\mathrm{H}$ and $\mathrm{O}$ agglutinins, whilst those against 
organisms grown at $37^{\circ}$ contained only $\mathrm{O}$ agglutinins. A similar absence of $\mathbf{H}$ agglutinin was found in the sera of rabbits immunized with a formalin killed broth culture grown at $37^{\circ}$.

Table 2. Agglutination titres of rabbit sera against $H$ and $O$ antigens

\begin{tabular}{|c|c|c|c|c|c|c|c|c|c|}
\hline \multirow{2}{*}{$\begin{array}{c}\text { Serum: } \\
\text { Antigen: }\end{array}$} & \multirow{2}{*}{$\begin{array}{l}\cdots \\
\cdots\end{array}$} & \multicolumn{2}{|c|}{$\begin{array}{ll}\ldots & \mathbf{A}\end{array}$} & \multicolumn{2}{|c|}{ B } & \multicolumn{2}{|c|}{ C } & \multicolumn{2}{|c|}{ D } \\
\hline & & $\ldots \mathbf{H}$ & $\mathrm{O}$ & $\mathbf{H}$ & O & $\mathrm{H}$ & $\mathrm{O}$ & $\mathbf{H}$ & O \\
\hline Rabbit no. & $\begin{array}{r}\text { Immunized } \\
\text { organisms } \\
\text { at }\end{array}$ & $\begin{array}{l}\text { th } \\
\text { wn }\end{array}$ & & & & & & & \\
\hline 1 & $22^{\circ}$ & 0 & 0 & 5,000 & 500 & 10,000 & 2,500 & 20,000 & 5,000 \\
\hline 2 & $22^{\circ}$ & 0 & 0 & 2,500 & 0 & 20,000 & 125 & 50,000 & 5,000 \\
\hline 3 & $22^{\circ}$ & 0 & 0 & 125 & 25 & 2,500 & 1,000 & 10,000 & 2,500 \\
\hline 4 & $37^{\circ}$ & 0 & 0 & o & 25 & 0 & 125 & 0 & 2,500 \\
\hline 5 & $37^{\circ}$ & 0 & 0 & 0 & 0 & 0 & 250 & 0 & 1,000 \\
\hline 6 & $37^{\circ}$ & 0 & 0 & 0 & 25 & 0 & 250 & 0 & 1,000 \\
\hline
\end{tabular}

A, serum taken before immunization; B, serum taken after first series of three injections; $C$, serum taken after second series of three injections; $D$, serum taken after third series of three injections.

Although these results are highly suggestive of an absence of $\mathrm{H}$ antigen in organisms grown at $37^{\circ}$, confirmation was sought by the absorption of immune serum. Sera with high titres of both $\mathbf{H}$ and $\mathbf{O}$ agglutinins were pooled, diluted $1 / 5$, mixed with equal volumes of very heavy suspensions of organisms grown for 3 days at 22 or $37^{\circ}$, and left in contact overnight at 22 and $37^{\circ}$ respectively. 'The titres of these absorbed sera against $\mathbf{H}$ and $\mathbf{O}$ suspensions were as follows:

$\begin{array}{lcc} & \mathrm{H} & \mathrm{O} \\ \text { Serum absorbed with living } 37^{\circ} \text { suspension } & 10,000 & <25 \\ \text { Serum absorbed with formolized } 3 \text { r }^{\circ} \text { suspension } & 10,000 & 1000 \\ \text { Control kept at } 37^{\circ} & \mathbf{1 0 , 0 0 0} & \mathbf{2 5 0 0} \\ \text { Serum absorbed with living } 22^{\circ} \text { suspension } & <\mathbf{2 5} & <\mathbf{2 5} \\ \text { Serum absorbed with formolized } 22^{\circ} \text { suspension } & \mathbf{2 5}(\mathrm{tr} .) & 1000 \\ \text { Control kept at } \mathbf{2 2}^{\circ} & \mathbf{2 0 , 0 0 0} & 1000\end{array}$

Organisms grown at $22^{\circ}$ absorbed both $\mathrm{H}$ and $\mathrm{O}$ agglutinins while those grown at $37^{\circ}$ absorbed only $\mathrm{O}$ agglutinins. Treatment with formalin reduced the capacity of the organisms to absorb $\mathbf{O}$ agglutinin.

These experiments show that organisms grown at $\mathbf{2 2}^{\circ}$ were motile, possessed peritrichate flagella, gave rise to the production of $\mathbf{H}$ agglutinin in rabbits, and absorbed this antibody from immune serum. On the other hand, organisms grown at $37^{\circ}$ were non-motile, possessed no flagella, did not cause the production of $\mathbf{H}$ agglutinin in rabbits, and were unable to absorb $\mathbf{H}$ agglutinin from immune serum. In each case there was complete correlation between the morphological and serological properties of this strain of Past. pseudotuberculosis.

There are several possible explanations for this difference associated with temperature:

(1) The establishment of different physico-chemical conditions in cultures at the two temperatures, e.g. different $\mathrm{pH}$ values. 
(2) The production of an enzyme which at $37^{\circ}$ would destroy the flagella or some substance essential for their synthesis (cf. streptococcal proteinaseElliott, 1945).

(3) Mutation, and subsequent selection determined by the temperature of incubation.

(4) The use of different metabolic processes at the two temperatures. (Cf. amino-acid requirements of Past. pestis, Hills \& Spurr, 1952.)

\section{The influence of $\mathrm{pH}$}

Cultures in digest broth inoculated with motile organisms and incubated at 22 and at $37^{\circ}$ were examined at intervals for motility, and the $\mathrm{pH}$ was estimated. The $22^{\circ}$ cultures were actively motile; those grown at $37^{\circ}$ showed only slight motility up to $24 \mathrm{hr}$. after which they were non-motile. At both temperatures, the $\mathrm{pH}$ showed an initial fall and subsequent rise (see Table 3 ). The changes in $\mathrm{pH}$ occurred faster at $37^{\circ}$, corresponding with more rapid growth, but otherwise they were similar at each temperature.

Table 3. Changes in $\mathrm{pH}$ of cultures at $22^{\circ}$ and at $37^{\circ}$

$\begin{array}{ccc}\begin{array}{c}\text { Age of } \\ \text { culture } \\ \text { (hr.) }\end{array} & \begin{array}{c}\text { pH of } \\ \text { culture grown } \\ \text { at } 22^{\circ}\end{array} & \begin{array}{c}\mathrm{pH} \text { of } \\ \text { culture grown } \\ \text { at } 37^{\circ}\end{array} \\ 0 & 7 \cdot 7 & 7 \cdot 7 \\ 6 & 7 \cdot 7 & 7 \cdot 55 \\ 12 & 7 \cdot 2 & 7 \cdot 2 \\ 18 & 7 \cdot 15 & 7 \cdot 15 \\ 24 & 7 \cdot 1 & 7 \cdot 2 \\ 36 & 7 \cdot 15 & 7 \cdot 4 \\ 48 & 7 \cdot 2 & 7 \cdot 6 \\ 72 & 7 \cdot 6 & 7 \cdot 55\end{array}$

Fach figure represents the average $\mathrm{pH}$ of two cultures.

In another experiment, digest broth was adjusted to $\mathrm{pH} 5 \cdot 5,6 \cdot 0,6 \cdot 5,7 \cdot 0$, $7 \cdot 5,8 \cdot 0,8 \cdot 5,9 \cdot 0,9 \cdot 5$. Substrains $134 / 22$ and $134 / 37$ were each used to inoculate a series of tubes covering the entire range which were incubated at 22 and $37^{\circ}$ respectively. Overnight cultures at $22^{\circ}$ were all motile; those at $37^{\circ}$ were all non-motile. These experiments leave little doubt that the differences between organisms grown at the two temperatures are not due to differences in $\mathrm{pH}$.

\section{Search for a destructive enzyme}

If the failure to produce flagella at $37^{\circ}$ were due to the action of a destructive enzyme, such an enzyme might possibly be demonstrated in filtrates of $37^{\circ}$ cultures. Broth cultures of strain 134 grown for $18 \mathrm{hr}$. at 22 and $37^{\circ}$ were Seitz-filtered. Samples of each filtrate were re-inoculated and incubated for $18 \mathrm{hr}$. at both 22 and $37^{\circ}$. Of these four cultures, the two which were grown at $22^{\circ}$ (one in a $22^{\circ}$ filtrate, the other in a $37^{\circ}$ filtrate) were actively motile and showed no apparent difference in flagellation. Those grown at $37^{\circ}$ were nonmotile. This experiment did not eliminate the possibility of an enzyme which acted effectively only at $37^{\circ}$ or of one which was adsorbed on to a Seitz filter. 
Evidence against these possibilities was provided by observations on tubes of broth which were inoculated with motile cells from a Craigie tube culture of strain $134 / 22$. After 1 day at $37^{\circ}$, these cultures contained a few motile cells and stained deposits showed occasional flagellated organisms some of which were faintly stained. After 2 days at $37^{\circ}$, the cultures were non-motile, but stained deposits still showed some flagellated cells, though these were all faintly stained and presumably dead. Considering the relatively rapid fall in viability of $37^{\circ}$ cultures, revealed in a later experiment, it seems likely that these flagellated cells were part of the inoculum and that they died at $37^{\circ}$ without destruction of their flagella. In view of the enormous preponderance of non-flagellated cells in these cultures the survival of a few flagella renders most unlikely the possibility that the non-flagellates produce an enzyme which can destroy flagella.

Although these experiments yield no evidence of an enzyme capable of destroying formed flagella, there remains the possibility of an enzyme which attacks at $37^{\circ}$ some substance necessary for the formation of flagella. Such a mechanism would appear, however, to be closely related to the utilization of different synthetic pathways at the two temperatures, and this will be discussed later.

\section{'Short-term' and 'long-term' influence of temperature}

The problem was to determine whether a culture is motile at $\mathbf{2 2}^{\circ}$ as a result of the production of motile mutants, or whether a different metabolic process occurs at $22^{\circ}$ which enables the bacteria to develop flagella. Some light was thrown on this problem by a study of the time-factor involved in the development of motility at $22^{\circ}$ and the loss of motility at $37^{\circ}$.

Broth cultures of strains $134 / 22$ and $134 / 37$ were incubated at 22 and $37^{\circ}$. They were examined for motility after 1, 2 and 3 days, and on each occasion the culture grown at $37^{\circ}$ was placed at $22^{\circ}$ and re-examined $2 \mathrm{hr}$. later. The results are shown in Table 4 . Strain $134 / 37$ grown at $22^{\circ}$ had a considerable

Table 4. Motility of strain $134 / 22$ and $134 / 37$ at $22^{\circ}$ and at $37^{\circ}$

\begin{tabular}{|c|c|c|c|c|}
\hline Strain & $\begin{array}{c}\text { Temperature } \\
\text { of } \\
\text { incubation }\end{array}$ & 1 day & 2 days & 3 days \\
\hline $134 / 22$ & $22^{\circ}$ & $90 \%$ actively motile & $50 \%$ actively motile & $50 \%$ actively motile \\
\hline $134 / 22$ & $37^{\circ}$ & $\begin{array}{l}\text { Occasional cell very } \\
\text { sluggishly motile-- } \\
\text { rotating with little } \\
\text { progress }\end{array}$ & Non-motile & Non-motile \\
\hline & $+2 \underset{22^{\circ}}{+2 \mathrm{hr} \text { at }}$ & $\begin{array}{l}\text { More cells motile, } \\
\text { and more active }\end{array}$ & $\begin{array}{l}\text { Occasional cell } \\
\text { rotating with little } \\
\text { progress }\end{array}$ & Non-motile \\
\hline
\end{tabular}

134/37 $\quad 22^{\circ} \quad 50 \%$ actively motile $\quad 50 \%$ actively motile $50 \%$ actively motile (not as fast as strain 134/22)

$134 / 37$

$\begin{array}{cccc}37^{\circ} & \text { Non-motile } & \text { Non-motile } & \text { Non-motile } \\ +\mathbf{2} \mathrm{hr} \text {. at } & \text { Non-motile } & \text { Non-motile } & \text { Non-motile } \\ \mathbf{2 2 ^ { \circ }} & & & \end{array}$


degree of motility after $24 \mathrm{hr}$; ; strain $134 / 22$ grown at $37^{\circ}$ for $24 \mathrm{hr}$. had only a few sluggishly motile cells, probably from the inoculum.

In addition to this immediate or 'short-term' effect of temperature there was a cumulative or 'long-term' effect. Strain $134 / 22$ grown at $37^{\circ}$ developed some motility $2 \mathrm{hr}$. after transferring it to $22^{\circ}$, whereas strain $134 / 37$ required longer. After $24 \mathrm{hr}$. at $22^{\circ}$ strain $134 / 22$ was more actively motile than strain $134 / 37$.

\section{The mechanism of the short-term effect}

If the effect of temperature was to alter enzymic activity, it might be possible to demonstrate this in resting cells. Therefore broth cultures grown at either 37 or $22^{\circ}$ until they reached the stationary phase were kept at the opposite temperature. Under these conditions changes in motility could be observed when there was little or no multiplication of the organisms. Viable organisms were estimated by counting colonies on blood agar by the method of Miles \& Misra (1938); total counts were made in a Thoma blood-counting chamber. Microscopic clumps which formed in broth cultures at $22^{\circ}$, and to a greater extent at $37^{\circ}$, were broken up, without lowering their viability, by rapid shaking in a vibrator. Trials indicated that the error in the viable count was unlikely to exceed $\pm 15 \%$, whilst that of the total count was probably less than $\pm 10 \%$; these figures refer to the relative counts of different cultures, not to the absolute values of the total and viable counts.

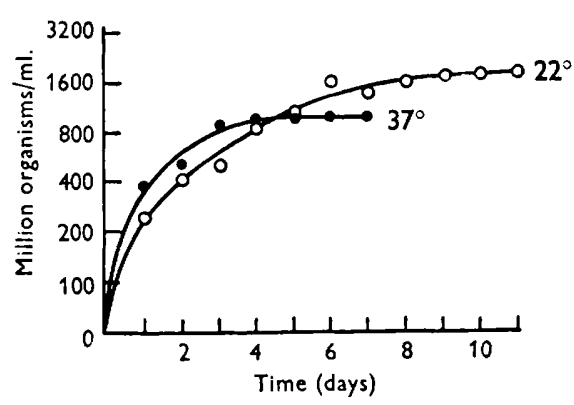

$\boldsymbol{a}$

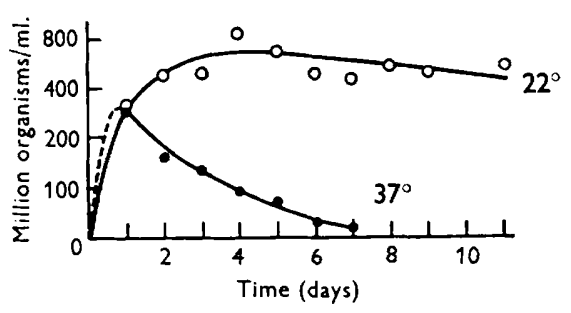

$b$

Fig. 1. a, growth of Past. pseudotuberculosis, strain 134, in digest broth (total counts); b, growth of Past. pseudotuberculosis, strain 134, in digest broth (viable counts).

Digest broth cultures of strain 134 reached the stationary phase at $37^{\circ}$ after 3-4 days; at $22^{\circ}$ multiplication was active up to about 5 days but later was much slower (Fig. 1). An experiment based on these findings was made to test the effect of change of temperature on cells which were not dividing. Tubes of digest broth were inoculated with a motile culture from a Craigie tube. After incubation at $37^{\circ}$ for 4 days (A) some tubes were transferred to $22^{\circ}$ for 1 day $(\mathrm{B})$; a control was incubated at $37^{\circ}$ for 5 days $(\mathrm{C})$. Other tubes were incubated at $22^{\circ}$ for 5 days $(\mathrm{D})$ and some of them transferred to $37^{\circ}$ for 2 days $(\mathrm{E})$; a control was kept at $22^{\circ}$ for 7 days $(\mathrm{F})$. Motility, flagella, total and viable counts are shown in Table $\mathbf{5}$. 
Table 5. Effect of change of temperature on cultures which have reached the stationary phase

\begin{tabular}{|c|c|c|c|c|c|}
\hline Culture & $\begin{array}{l}\text { Time and } \\
\text { temperature } \\
\text { of incubation }\end{array}$ & $\begin{array}{c}\text { Total } \\
\text { count } \\
\text { (million/ } \\
\text { ml.) }\end{array}$ & $\begin{array}{c}\text { Viable } \\
\text { count } \\
\text { (million/ } \\
\text { ml.) }\end{array}$ & $\begin{array}{c}\text { Hanging } \\
\text { drop }\end{array}$ & Stained deposit \\
\hline $\mathbf{A}$ & 4 days at $37^{\circ}$ & 840 & 300 & Non-motile & None flagellate \\
\hline B & $A+1$ day at $22^{\circ}$ & 800 & 320 & $\begin{array}{l}\text { About } 30-40 \% \\
\text { motile }\end{array}$ & $\begin{array}{l}\text { About } 30 \% \text { flagellate } \\
\text { (peritrichate)-all } \\
\text { these deeply stained }\end{array}$ \\
\hline $\mathrm{C}$ & $A+1$ day at $37^{\circ}$ & $\mathbf{8 4 0}$ & 280 & Non-motile & None flagellate \\
\hline D & 5 days at $22^{\circ}$ & 990 & 625 & $\begin{array}{l}\text { About } 40-50 \% \\
\text { motile }\end{array}$ & $\begin{array}{l}\text { About } 70 \% \text { flagellate } \\
\text { (peritrichate)-about } \\
\text { one third of these } \\
\text { pale }\end{array}$ \\
\hline $\mathbf{E}$ & $\mathrm{D}+2$ days at $37^{\circ}$ & 880 & 100 & $\begin{array}{l}\text { Less than } 5 \% \\
\text { motile (sluggish) }\end{array}$ & $\begin{array}{l}\text { About } 70 \% \text { flagellate } \\
\text { - most of these pale } \\
\text { (deeply stained cells } \\
\text { had not more than } \\
\text { three flagella: most } \\
\text { had none or one) }\end{array}$ \\
\hline $\mathbf{F}$ & $\mathrm{D}+2$ days at $22^{\circ}$ & 960 & 500 & $\begin{array}{l}\text { About } 40-50 \% \\
\text { motile }\end{array}$ & $\begin{array}{l}\text { About 70\% flagellate } \\
\text { (peritrichate)-about } \\
\text { half of these pale }\end{array}$ \\
\hline
\end{tabular}

About one-third of the bacteria in B became motile during $\mathbf{2 4} \mathrm{hr}$. at $\mathbf{2 2}^{\circ}$ without a significant change in the total or viable count. That this was a result of temperature is shown by $\mathrm{C}$; cells which were non-motile at $37^{\circ}$ became motile at $\mathbf{2 2}^{\circ}$, a finding that would explain the temperature effect without recourse to mutation. The only other possibility was that the motile cells were newly formed as replacements for lysed cells, but there was no evidence to support this view: examination of hanging drops and stained films did not show any abnormal cells indicative of autolytic processes, and, moreover, many of the motile cells were long rods, the form usually found in cultures grown at $37^{\circ}$.

Conversely, cells which were motile when grown at $22^{\circ}$ (D) became nonmotile after a further 2 days at $37^{\circ}(\mathrm{E})$, a change that did not occur at $22^{\circ}(\mathrm{F})$ and was therefore a temperature effect.

This loss of motility when flagellated cells grown at $\mathbf{2 2}^{\circ}$ were kept for 2 days at $37^{\circ}$ was associated with fall in viable count, inability of large numbers of cells to stain with normal intensity (Table 5) and, in addition, the presence of large numbers of poorly refractile organisms, 'ghost-cells' seen in hanging-drop preparations, indications of an adverse effect of a temperature of $37^{\circ}$ on the viability of the cell in the medium employed. Loss of motility was not due to loss of flagella but probably was a manifestation, perhaps an early one, of conditions found in digest broth at $37^{\circ}$, not operative at $\mathbf{2 2}^{\circ}$, which were unfavourable to survival of the bacteria. The nature of these conditions and the mechanism of their effect are not known. It is probable, however, that the factors which suppress development of flagella at $37^{\circ}$ also bring about the loss of motility when motile cells grown at $22^{\circ}$ are 
kept at $37^{\circ}$ and account for the high death-rate of bacteria at $37^{\circ}$. The temperature effect which suppresses the production of flagella or abolishes motility in flagellated organisms is not due to mutation; a more likely explanation is that certain metabolic processes are conditioned by temperature. Thus the short-term effects of temperature, both 22 and $37^{\circ}$, have a similar explanation; the metabolic processes at these two temperatures appear to be different.

It may be noted that motility in culture $\mathrm{E}$ grown at $22^{\circ}$ and kept at $37^{\circ}$ (Table 5) was not completely abolished and that some of the cells were deeply stained and had flagella. These cells were probably some which had developed at $\mathbf{2 2}^{\circ}$; there was no evidence that new cells were produced in this culture at $37^{\circ}$. However the possibility cannot be completely excluded that a few flagellated cells may have been formed at $37^{\circ}$. A motile strain inoculated into a Craigic tube and incubated at $37^{\circ}$ grew through the medium for a time; perhaps some motile cells retained for a time some stored-up material which enabled them to use their flagella at $37^{\circ}$ and even develop a few new flagella but that this soon came to an end. Two-day cultures in broth at $37^{\circ}$ were non-motile and $48 \mathrm{hr}$. cultures on blood agar at $37^{\circ}$ had no detectable $\mathbf{H}$ antigen.

The development of flagella at $\mathbf{2 2}^{\circ}$ without cell division was also observed in nutrient broth, measuring density with a nephelometer. Cultures were inoculated with motile organisms, incubated for 2 days at $37^{\circ}$, and overnight at $22^{\circ}$. In one case about $15 \%$ of the cells had become motile without increase in opacity; in the other there was an increased opacity of about $4 \%$ but about $\mathbf{2 5} \%$ had become motile. Similar results were obtained with four other strains of Past. pseudotuberculosis belonging to different serological types. Three further strains required four passages through Craigie tubes before becoming actively motile at $\mathbf{2 2}^{\circ}$, and then gave similar results.

\section{The long-term effect}

A difference in the properties of the two substrains, induced by repeated subculture at 22 and $37^{\circ}$ was demonstrated by comparing the rates of progress of their growth in Craigie tubes at $22^{\circ}$. Overnight broth cultures of the two substrains $134 / 22$ and $134 / 37$ of approximately equal density, were used. Each was grown at 22 and $37^{\circ}$ and inoculated with a straight wire into five Craigie tubes which were incubated at $\mathbf{2 2}^{\circ}$. All these tubes were similar in size. The progress of the growth down the central tube and up the outer part of the medium was recorded daily, the measurements of the five tubes of each series being averaged, as shown in Table 6 and Fig. 2. It is clear that the two substrains, as a result of prolonged cultivation at different temperatures, differed in their ability to grow and produce motile organisms at $22^{\circ}$ and that this difference depended more on properties acquired by long-term cultivation than the conditions of the culture immediately preceding their inoculation. Substrain 134/22, accustomed to grow at a temperature suitable for motility, made faster progress through a Craigie tube at $22^{\circ}$ than substrain $134 / 37$, accustomed to grow at a temperature which precluded the formation of 
flagella. This was so whether the culture used as inoculum was motile or non-motile.

The long-term effect was also demonstrated by a difference in the rate of growth in digest broth, using a nephelometer. Substrains 134/22 and 134/37 were equal at $37^{\circ}$, but at $22^{\circ}$ substrain $134 / 22$ grew considerably faster (Fig. $3 a, b)$.

Table 6. Rate of progress in Craigie tubes at $\mathbf{2 2}^{\circ}$

\begin{tabular}{|c|c|c|c|c|c|c|}
\hline \multirow[b]{2}{*}{ Group } & \multirow[b]{2}{*}{ Tube } & \multicolumn{5}{|c|}{ Distance in $\mathrm{mm}$. from point of inoculation } \\
\hline & & 1 day & 2 days & 3 days & 4 days & 5 days \\
\hline \multirow[t]{6}{*}{$\mathbf{I}$} & 1 & 13 & $\mathbf{3 7}$ & $72+$ & - & - \\
\hline & 2 & 15 & 38 & 62 & $70+$ & - \\
\hline & 3 & 10 & 28 & Broken & - & - \\
\hline & 4 & 17 & 34 & $64+$ & - & - \\
\hline & 5 & 13 & 33 & 58 & $61+$ & - \\
\hline & Av. & 14 & 34 & $64+$ & - & - \\
\hline \multirow[t]{6}{*}{ II } & 1 & 10 & 29 & 57 & $68+$ & - \\
\hline & 2 & 12 & 34 & 55 & $64+$ & - \\
\hline & 3 & 13 & 34 & 62 & $64+$ & - \\
\hline & 4 & 12 & 35 & 60 & $66+$ & - \\
\hline & 5 & 9 & 24 & 54 & $65+$ & - \\
\hline & Av. & 11 & 31 & 58 & - & $\longrightarrow$ \\
\hline \multirow[t]{6}{*}{ III } & 1 & 9 & 21 & 37 & 54 & $69+$ \\
\hline & 2 & 13 & 25 & 39 & 59 & $73+$ \\
\hline & 3 & 11 & 22 & 36 & $66+$ & - \\
\hline & 4 & 8 & 21 & 31 & $60+$ & - \\
\hline & 5 & 8 & 21 & 34 & $65+$ & - \\
\hline & Av. & 10 & 22 & 35 & $61+$ & - \\
\hline \multirow[t]{6}{*}{ IV } & 1 & 5 & 16 & 36 & 51 & $68+$ \\
\hline & 2 & 6 & 35 & 47 & $67+$ & - \\
\hline & 3 & 7 & 14 & 34 & 45 & $64+$ \\
\hline & 4 & 8 & 20 & 35 & $62+$ & - \\
\hline & $\mathbf{5}$ & 6 & 20 & 33 & $62+$ & - \\
\hline & Av. & 6 & 21 & 37 & $57+$ & - \\
\hline
\end{tabular}

I, inoculated with strain 134/22 grown overnight at $22^{\circ}$ (motile inoculum); II, inoculated with strain 134/22 grown overnight at $37^{\circ}$ (inoculum almost non-motile); III, inoculated with strain 134/37 grown overnight at $22^{\circ}$ (motile inoculum); IV, inoculated with strain 134/37 grown overnight at $37^{\circ}$ (non-motile inoculum); +indicates that the surface of the outer part of the medium had been reached.

Preliminary experiments have shown that the long-term effect is reversible. If substrain 134/37 is grown continually at $22^{\circ}$ it assumes the properties described above for substrain 134/22 ; similarly, substrain $134 / 22$ may be made to acquire the properties of substrain $134 / 37$ by cultivating it for a period at $37^{\circ}$.

The probable explanation of this long-term effect is that it is a continuation of the short-term effect of temperature, the organism being trained, or becoming adapted, to use different metabolic processes more efficiently after repeated subculture. As the short-term effect can be explained apart from the gradual selection of a naturally occurring mutant, it would seem unnecessary to introduce such a postulate to explain the long-term effect. 


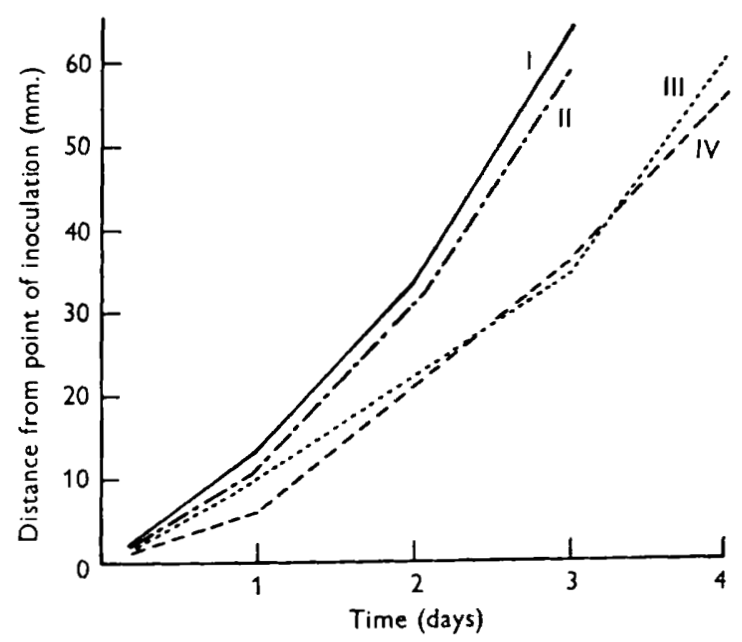

Fig. 2. Progress of Past. pseudotuberculosis in Craigie tubes at $22^{\circ}$. I, inoculated from overnight broth culture of strain $134 / 22$ grown at $22^{\circ}$ (motile inoculum); II, inoculated from overnight broth culture of strain $134 / 22$ grown at $37^{\circ}$ (inoculum almost non-motile); III, inoculated from overnight broth culture of strain $134 / 37$ grown at $22^{\circ}$ (motile inoculum); IV, inoculated from overnight broth culture of strain 134/37 grown at $37^{\circ}$ (non-motile inoculum).

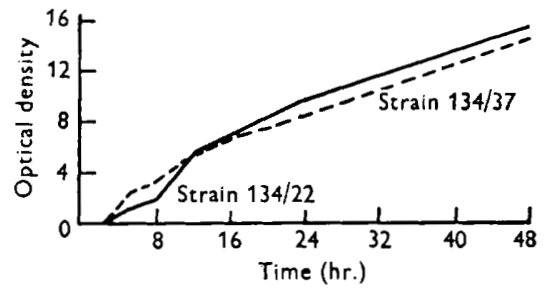

$a$

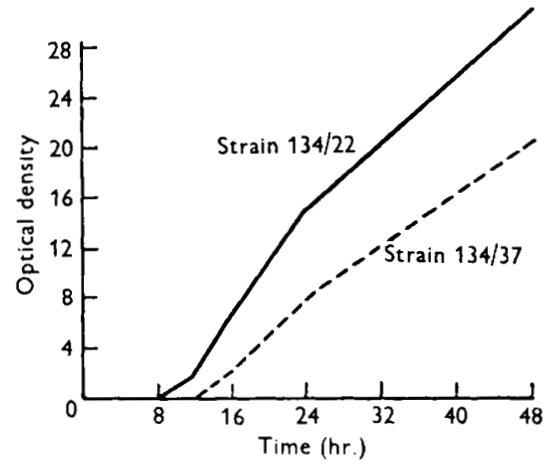

$b$

Fig. 3. a, growth of Past. pseudotuberculosis in digest broth at $37^{\circ}$; $b$, growth of Past. pseudotuberculosis in digest broth at $22^{\circ}$.

\section{Virulence for mice}

Preliminary experiments have indicated that organisms grown in digest broth at $22^{\circ}$ were more virulent for mice than those grown at $37^{\circ}$. This confirms one of the findings of Boquet (1937). It would seem unlikely from analogy that this phenomenon is related to the presence or absence of flagella. Further investigations are in progress.

We are grateful to Mr F. Ward and Mr H. W. Gaze for the photographs. 


\section{REFERENCES}

Arkwright, J. A. (1927). The importance of motility of bacteria in classification and diagnosis, with special reference to B. pseudotuberculosis rodentium. Lancet, i, 13.

Bhatnagar, S. S. (1940). Bacteriological studies on Past. pestis and Past. pseudotuberculosis. Indian J. med. Res. 28, 1.

Boquet, P. (1937). Recherches expérimentales sur la pseudo-tuberculose des rongeurs. Ann. Inst. Pasteur, 59, 341.

Cons, H. J. \& Wolfe, G. E. (1938). Flagella staining as a routine test for bacteria. J. Bact. 36, 517 .

ElliotT, S. D. (1945). A proteolytic enzyme produced by group A streptococei with special reference to its effect on the type-specific M antigen. J.exp. Med. 81, 573.

Hills, the late G. M. \& SPurr, E. D. (1952). The effect of temperature on the nutritional requirements of Pasteurella pestis. J. gen. Microbiol. 6, 64.

Leifson, E. (1930). A method of staining bacterial flagella and capsules together with a study of the origin of flagella. J. Bact. 20, 203.

Miles, A. A. \& MisRa, S. S. (1938). The estimation of the bactericidal power of the blood. J. Hyg., Camb. 38, 732.

SchÜтze, H. (1932). Studies in B. pestis antigens. Brit. J. exp. Path. 13, 284.

Weitzenberg, R. (1935). Über die Beweglichkeit des Bac. pseudotuberculosis rodentium (A. Pfeiffer). Zbl. Bakt. 133, 343.

\section{EXPLANATION OF PLATE,}

Photomicrographs of Past. pseudotuberculosis stained to show flagella.

Fig. 1. Grown at $22^{\circ}$ on nutrient agar. $\times 600$.

Fig. 2. Grown at $22^{\circ}$ in broth. $\times \mathbf{7 0 0}$.

Hig. 3. Grown at $37^{\circ}$ in broth. $\times 700$.

(Received 9 February 1952) 
Journal of General Microbiology, Vol. 7, Nos. 1 \& 2
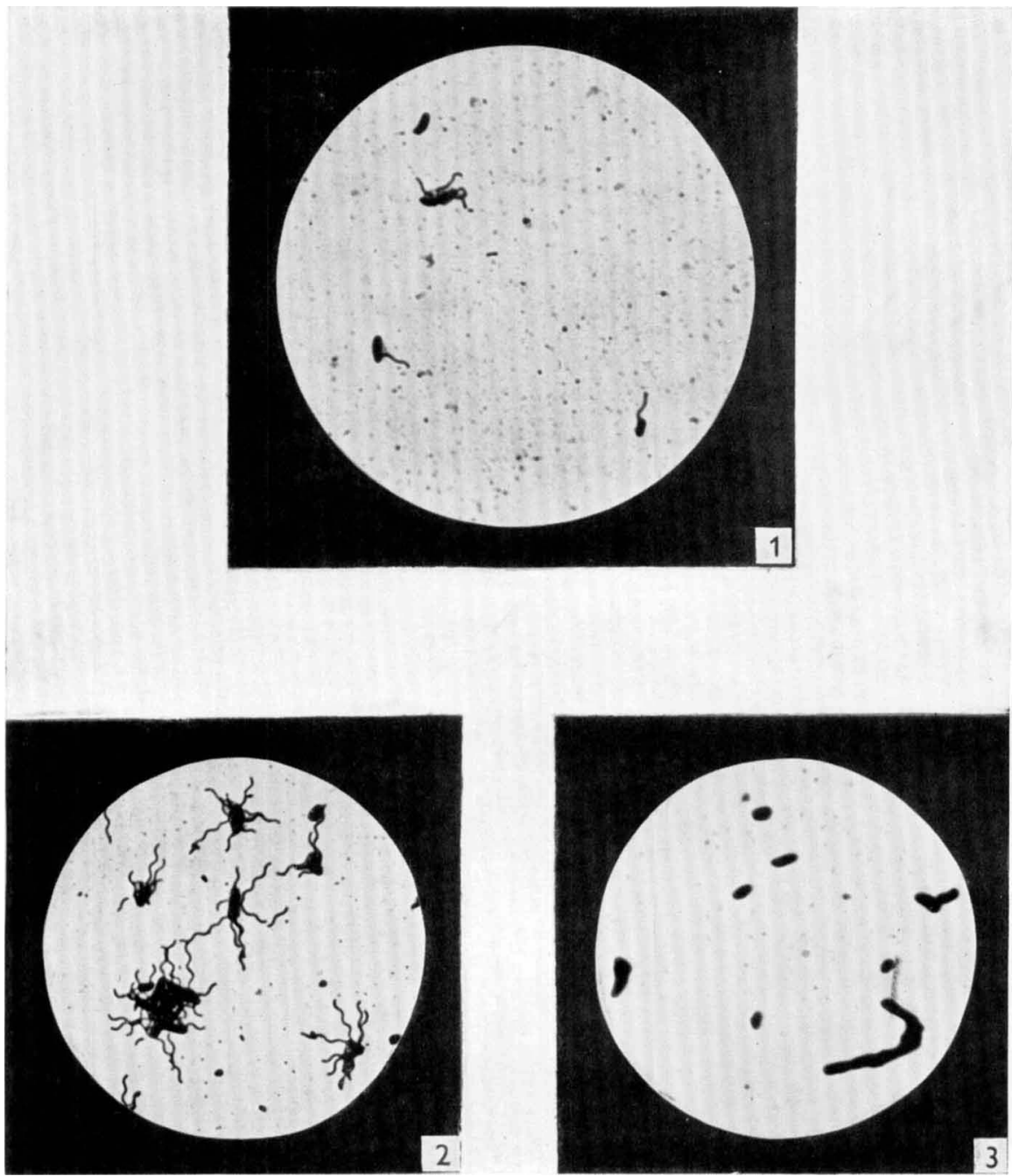

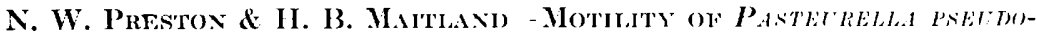
tublaclaosis. Piate 1 